Pawet Blajer

\title{
Ewolucja szczególnej regulacji obrotu gruntami rolnymi w ustawodawstwie hiszpańskim
}

\section{Uwagi wstępne}

Pomimo istotnych różnic w zakresie doświadczeń historycznych oraz uwarunkowań politycznych i gospodarczych ustawodawstwa hiszpańskie i polskie w zakresie prawnej reglamentacji obrotu nieruchomościami rolnymi wykazują zadziwiająco wiele analogii. Okoliczność ta wynika przede wszystkim z faktu, że zarówno polskie, jak i hiszpańskie rozwiązania odnoszące się do obrotu gruntami rolnymi w żadnym wypadku nie charakteryzują się ciągłością przyjmowanych regulacji, ani też konsekwencją w urzeczywistnianiu raz przyjętych koncepcji. Wręcz przeciwnie, cechą charakterystyczną obu tych porządków prawnych są niejednokrotnie wręcz gorączkowe poszukiwania legislacyjne.

Hiszpańskie i polskie ustawodawstwa agrarne to również legislacje eklektyczne, w wysokim stopniu nieoryginalne, poddające się wpływom zewnętrznym. W przypadku Hiszpanii największe znaczenie mają początkowo inspiracje włoskie i francuskie, w późniejszym okresie do głosu dochodzą koncepcje wypracowane przede wszystkim w ramach Wspólnej Polityki Rolnej, ale pojawiają się również zapożyczenia z germańskich systemów prawa.

$\mathrm{Z}$ wyżej wymienionych względów, analizując dorobek hiszpańskiego ustawodawcy tylko i wyłącznie w minionym półwieczu, można zauważyć ciągłą zmianę przyjmowanych rozwiązań, opracowywanie nowych pojęć i zarzucanie poprzednich. Tym również należy zapewne tłumaczyć krótki ,żywot” wielu aktów prawnych, dotyczących problematyki obrotu gruntami rolnymi, zastępowanych nowymi, które w założeniu ustawodawcy lepiej miały odpowiadać zmieniającym się stosunkom społeczno-gospodarczym. Ze względu na wyżej opisaną specyfikę przyjętych regulacji, wskazane wydaje się być przedstawienie hiszpańskiego dorobku w tym zakresie w ujęciu historycznym jako pewnego dynamicznego procesu, polegającego na ciągłym poszukiwaniu nowych, lepszych rozwiązań. 
Przyjmując zatem podejście historyczne jako główne założenie metodologiczne niniejszego opracowania, podkreślić należy, że w dużym uproszczeniu historię szczególnej regulacji obrotu nieruchomościami rolnymi w Hiszpanii po II wojnie światowej można podzielić na trzy zasadnicze okresy:

1) okres reformy rolnej, wyznaczony dekretem numer 118/1973 z dnia 12 stycznia 1973 roku o reformie i rozwoju rolnictwa ${ }^{1}$,

2) okres surowej reglamentacji, wyznaczony uchyloną już ustawą numer 49/1981 z dnia 24 grudnia 1981 roku o statucie rodzinnego gospodarstwa rolnego oraz młodych rolników ${ }^{2}$,

3) okres stopniowej liberalizacji, trwający do chwili obecnej, a rozpoczynający się wraz z uchyleniem cytowanej ustawy z 1981 roku przez aktualnie obowiązującą ustawę numer 19/1995 z dnia 4 lipca 1995 roku o modernizacji gospodarstw rolnych ${ }^{3}$.

Już pobieżny rzut oka na zarysowaną powyżej periodyzację wywołuje skojarzenia $\mathrm{z}$ analogicznymi rozwiązaniami przyjętymi przez polskiego ustawodawcę w zakresie prawnej reglamentacji obrotu nieruchomościami rolnymi, oczywiście z uwzględnieniem nieco zmodyfikowanych granic czasowych. Tym samym względy teoretyczne przemawiają za podjęciem próby prześledzenia tych regulacji prawnych, za pomocą których ustawodawca hiszpański, w diametralnie przecież różnych realiach społeczno-gospodarczych, zmierzał do osiągnięcia celów zbliżonych co do zasady do założeń, które na przestrzeni lat przyświecały również legislatorowi polskiemu.

Potrzebę bliższej analizy rolnego ustawodawstwa hiszpańskiego uzasadnia również brak, jak do tej pory, szerszych opracowań poświęconych temu porządkowi prawnemu w literaturze polskiej. Co prawda w ostatnich latach ukazało się w Polsce kilka istotnych pozycji nawiązujących między innymi do prawnorolnych regulacji hiszpańskich ${ }^{4}$, jednak do dnia dzisiejszego nie pojawiły się prace koncentrujące się wyłącznie na dorobku hiszpańskiego prawa rolnego, nie zostały również podjęte próby skonfrontowania tego dorobku z doświadczeniami polskimi.

Celem niniejszej pracy jest zatem podjęcie próby charakterystyki podstawowych tendencji rozwoju hiszpańskich regulacji w zakresie obrotu nieruchomościami rolnymi w ich aspekcie historycznym oraz ukazanie podstawowych wpływów, ja-

\footnotetext{
Boletin Oficial del Estado, num. 30 z 3 lutego 1973 r.

Boletin Oficial del Estado, num. 9 z 11 stycznia 1982 r.

Boletin Oficial del Estado, num. 159 z 5 lipca 1995 r.

Por. w szczególności: A. Lichorowicz, Status prawny gospodarstw rodzinnych w ustawodawstwie krajów Europy Zachodniej, Białystok, 2000; idem, W kwestii modelu prawnego instytucji kształtujących struktury gruntowe w rolnictwie, Studia luridica Agraria 2005, t. IV, s. 124 i n.; idem, Regulacja obrotu gruntami rolnymi według ustawy z 11 IV 2003 roku o kształtowaniu ustroju rolnego na tle ustawodawstwa agrarnego Europy Zachodniej, Studia luridica Agraria 2005, t. 5, s. 76; idem, Podstawowe rozwiąania w zakresie obrotu gruntami rolnymi w ustawodawstwie krajów Europy Zachodniej, Studia Prawnicze 2001, z. 3, s. 95 i n.
} 
kim na przestrzeni lat podlegało ustawodawstwo hiszpańskie. Tak zarysowane problemy badawcze wyznaczają zatem ramy niniejszej pracy, pozwalając jednocześnie na skonfrontowanie rozwiązań hiszpańskich z analogicznymi unormowaniami polskimi i wysunięcie określonych wniosków co do możliwości wykorzystania niektórych regulacji hiszpańskich w polskim porządku prawnym, które też poczynione zostaną w ramach uwag końcowych.

\section{Okres reformy rolnej - dekret numer 118/1973 z dnia 12 stycznia 1973 roku o reformie i rozwoju rolnictwa}

Dekret z 1973 roku stanowił kamień milowy w rozwoju hiszpańskiego ustawodawstwa rolnego i to nie tylko w zakresie obrotu nieruchomościami rolnymi ${ }^{5}$. Odwołując się zasadniczo do wzorów włoskich, ale i przynosząc wiele oryginalnych rozwiązań ${ }^{6}$, podsumowywał on dotychczasowe, niekiedy chaotyczne i rozsiane po różnych źródłach prawa regulacje odnoszące się do reformy rolnej w Hiszpanii, przynosząc ich ujednolicenie i w pewnym sensie kodyfikację. Podstawowe unormowania dekretu odnoszą się do Instytutu Reformy Rolnej i Rozwoju Rolnictwa (Instituto Nacional de Reforma y Desarrollo Agrario), jako autonomicznego organu administracji państwowej realizującego cele hiszpańskiej reformy rolnej. Z kolei jednym z zasadniczych celów tej reformy, zgodnie z przepisem art. 21 dekretu, miało być tworzenie ,gospodarstw rodzinnych” oraz, na wniosek właściciela, tzw. „,majątków rodzinnych". Oba te pojęcia doczekały się zresztą w przedmiotowym akcie prawnym szczegółowych definicji ustawowych:

Za gospodarstwo rodzinne (explotación familiar) należało uważać jednostki produkcyjne o wielkości i cechach zapewniających przyzwoity i godny poziom życia dla jednej rodziny rolniczej, pracującej osobiście (personalmente) i bezpośrednio (directe) w tym gospodarstwie w wymiarze dwóch jednostek pracy.

Z kolei „majątek rodzinny” (patrimonio familiar) powinien spełniać wszelkie przesłanki określone dla gospodarstwa rodzinnego, a ponadto powinien stanowić jedność ekonomiczną obejmującą grunty do niej przypisane, budynki gospodarcze, inwentarz żywy i martwy oraz generalnie dobra i prawa wchodzące w skład gospodarstwa i stanowiące własność tylko jednej osoby. Prowadzenie takiego gospodarstwa powinno realizować się poprzez osobistą i bezpośrednią pracę jego właściciela oraz członków jego rodziny, wspólnie z nim mieszkających i zależnych od niego ekonomicznie ze względu na wiek, płeć, inwalidztwo lub przeszkody prawne ${ }^{7}$. Kolejnym, formalnym warunkiem powstania „majątku rodzinnego” było powołanie go

\footnotetext{
$5 \quad$ Por. A. Aranda, La reforma agraria y derecho, Madrid 1957. Na temat znaczenia wymienionego dekretu wypowiada się również D. Llombart Bosch, Temas de Derecho Agrario, Valencia 1995, s. 32 i n. Por. A. Lichorowicz, Status prawny..., op. cit., s. 82 i n.

Szerzej na temat majątków rodzinnych: A. Soldevilla, La empresa agraria, Valladolid 1982, s. 182 i n.
} 
do życia w akcie notarialnym oraz wpis w księgach wieczystych (a właściwie w specjalnym rejestrze własności nieruchomości - Registro de la Propriedad - pełniącym w Hiszpanii niektóre funkcje ksiąg wieczystych w polskim rozumieniu) ${ }^{8}$.

Do utworzenia obu powołanych kategorii rolniczych jednostek produkcyjnych miały być wykorzystywane nieruchomości pochodzące z reformy rolnej. Grunty te, zakupione przez IRYDA, po przeprowadzeniu przez tę instytucję stosownych prac melioracyjnych oraz bonifikacyjnych oraz po dokonaniu odpowiednich zabiegów komasacyjnych, podlegały redystrybucji pomiędzy rolników. Powinna ona nastąpić maksymalnie w okresie trzech lat od nabycia tych nieruchomości przez IRYDA. Celem owej redystrybucji było utworzenie jednostek produkcyjnych spełniających kryteria dla uznania ich za gospodarstwa rodzinne lub majątki rodzinne, zaś formalnym sposobem jej dokonania było tzw. przysądzenie (adjudicacion), które wbrew nazwie następowało na podstawie decyzji administracyjnej - nadania (concession), wydawanej przez IRYDA. Absolutne pierwszeństwo do korzystania z dobrodziejstw reformy, a więc właśnie owych aktów nadania, przysługiwało szczególnej kategorii rolników, tzn. producentom bezpośrednim i indywidualnym, co oznacza, że w ramach szeroko zakrojonej akcji reformy rolnej ustawodawca hiszpański brał również pod uwagę względy natury podmiotowej, zmierzając do upowszechnienia własności rolniczej wśród osób odpowiednio przygotowanych do prowadzenia efektywnej działalności wytwórczej9.

Sam akt nadania, co charakterystyczne, nie przenosił jednak własności gospodarstwa lub majątku rodzinnego na osobę, na którą został wystawiony. Własność pozostawała bowiem tymczasowo zastrzeżona na rzecz IRYDA. Z drugiej strony, na rolnikach, którzy uzyskali taką decyzję administracyjną, aż do definitywnego przejścia na ich rzecz własności gruntów objętych aktem nadania, ciążył szereg niejednokrotnie mocno uciążliwych obowiązków. Przede wszystkim ograniczała ich daleko posunięta kontrola za strony IRYDA, jako właściciela nadanych rolnikom gruntów rolnych, wyrażająca się w wymogu uzyskiwania zezwolenia tej instytucji na szereg czynności prawnych dotyczących nadanych gospodarstw. Zezwolenia IRYDA, wydawanego w ramach uznania administracyjnego wyłącznie w sytuacji, gdy istniała ku temu słuszna przyczyna (causa justificada), wymagał:

- podział lub połączenie gospodarstw rodzinnych lub też przyłączenie do nich nowych nieruchomości,

Na temat znaczenia rejestru nieruchomości dla uzyskania przez gospodarstwo statusu „majątku rodzinnego” szeroko wypowiada się F. Corral Duenas, El registro de la propriedad y la legislacion social agraria, Madrid 1977, s. 133 in.

9 Szerokie rozważania na temat tego interesujacego pojęcia o charakterze podmiotowym, wzorowanego na włoskiej koncepcji producenta bezpośredniego, zawiera zarówno literatura hiszpańska, np. A. Garcia Royo, Tratado de arrendamientos rusticos, Madrid 1950, s. 99 i n.; A. Ballarin Marcial, Estudios de derecho agrario y politica agraria, Madrid 1973, s. 609 i n., jak i włoska, np.: T. Rava, La nozione giuridica di impresa, Milano 1949, s. 48 i n.; W. Bigiavi, La piccola impresa, Milano 1942, s. 60 i n. 
- zbycie lub obciążenie jakiejkolwiek z wchodzących w skład gospodarstwa nieruchomości, z dodatkowym zastrzeżeniem, że nieruchomości nabyte na miejsce tych zbytych, powinny stać się częścią gospodarstwa rodzinnego,

- zbycie gospodarstwa rodzinnego inter vivos.

Powyższy przepis dotyczył sytuacji rozporządzenia nadanym w toku reformy rolnej gospodarstwem rodzinnym lub poszczególnymi nieruchomościami wchodzącymi w jego skład. Brak zezwolenia administracyjnego na dokonanie wymienionych czynności skutkował bezwzględną ich nieważnością ${ }^{10}$.

Całość gospodarstwa w owym krytycznym okresie, kiedy nie stanowiło ono jeszcze własności rolnika, któremu zostało nadane, chroniona była nie tylko przed możliwymi podziałami w drodze czynności inter vivos, lecz również mortis cau$s a$. Ustawodawca hiszpański przewidział tu mocno kazuistyczną regulację, ustalając kolejność osób, na które przenoszono ów akt nadania w wypadku śmierci bezpośredniego adresata tej decyzji.

Stan pewnej tymczasowości, wywołany zastrzeżeniem własności gospodarstwa rodzinnego na rzecz IRYDA, trwał zasadniczo osiem lat. Przez cały ten czas osoba, na rzecz której wystawiono akt nadania musiała spełniać określone w art. 30 dekretu warunki, do których między innymi należał wymóg prowadzenia nadanego gospodarstwa w charakterze tzw. producenta bezpośredniego i indywidualnego.

Samo zaś przeniesienie własności nadanych nieruchomości rolnych następowało po upływie ustawowo przewidzianego okresu, na podstawie dokumentu publicznego wystawianego przez IRYDA. Osoba, która uzyskała taki dokument stawała się pełnoprawnym właścicielem nadanego jej uprzednio gospodarstwa, nieograniczonym już jakimikolwiek przepisami dekretu, jeśli chodzi o możliwość dysponowania nim w drodze czynności prawnych inter vivos i w niewielkim tylko zakresie ograniczonym w zakresie rozporządzania mortis causa.

Przywołane powyżej dyspozycje dekretu z 1973 roku prowadzą do konkluzji, że o ile w ośmioletnim okresie pomiędzy aktem nadania a ostatecznym przeniesieniem własności gospodarstwa, ustawodawca hiszpański przywiązywał dużą wagę do tego, by gospodarstwo rodzinne prowadzone było przez producenta bezpośredniego i indywidualnego (a więc osobę odpowiednio przygotowaną do prowadzenia działalności rolniczej) oraz dbał o jego całość i niepodzielność, o tyle po definitywnym przeniesieniu prawa własności kontrola co do spełniania jakichkolwiek przesłanek podmiotowych po stronie właściciela gospodarstwa rodzinnego oraz w zakresie ewentualnych działów była ograniczona, a w praktyce zupełnie nie istniała ${ }^{11}$.

Por. A. Ballarin Marcial, Estudios..., op. cit., s. 610.

Ibidem, s. 611. 
Zdecydowanie większą troskę o zachowanie posiadanego statusu producenta bezpośredniego i indywidualnego przejawia ustawodawca hiszpański odnośnie do osób prowadzących drugą z kategorii gospodarstw przewidzianych dekretem o reformie rolnej z 1973 roku, mianowicie „majątków rodzinnych”. Utworzenie takiej jednostki produkcyjnej następowało dopiero z momentem definitywnego przeniesienia własności nadanych nieruchomości rolnych i wymagało wniosku osoby, na której rzecz owo przeniesienie własności następowało, jak również formy aktu notarialnego oraz stosownego wpisu do rejestru własności. Tak powstałe „majątki rodzinne" korzystały w systemie hiszpańskim z daleko posuniętej ochrony, która miała na celu przede wszystkim zachowanie ich w całości i zapobieżenie niekorzystnym z gospodarczego punktu widzenia podziałom, zarówno prawnym, jak i faktycznym. Nieruchomości wchodzące w skład majątku rodzinnego stanowiły, jak stwierdza dekret, jedność prawnie niepodzielną. Ich podział był dopuszczalny tylko za zgodą ministra rolnictwa i to wyłącznie w przypadku, gdy części powstałe na skutek owego podziału spełniały wszystkie kryteria umożliwiające uzyskanie im statusu majątku rodzinnego. Zbycie majątku rodzinnego en bloc w drodze czynności prawnej inter vivos nastąpić mogło jedynie na rzecz innego producenta bezpośredniego i indywidualnego i dla swej ważności wymagało uprzedniej zgody ministra rolnictwa oraz wpisu do rejestru własności.

Bardzo skomplikowana i kazuistyczna, ale zmierzająca do utrzymania niepodzielności istniejącej jednostki produkcyjnej, była również prawna regulacja dziedziczenia majątków rodzinnych. Zgodnie bowiem z przepisem art. 41 dekretu, majątek rodzinny zasadniczo powinien przypaść osobie powołanej przez spadkodawcę w testamencie. Jednakże, jeśli spadkodawca pozostawił spadkobierców koniecznych, powołanie w testamencie było skuteczne, o ile powołany został właśnie jeden z takich spadkobierców. Natomiast jeśli spadkodawca powołał kilku spadkobierców jednocześnie, testament mógł zostać utrzymany w mocy, jeżeli na skutek podziału pomiędzy tych spadkobierców spadkowego majątku rodzinnego powstawały samodzielne majątki rodzinne spełniające wszystkie kryteria przepisane dla tej kategorii jednostek produkcyjnych. Gdy spadkodawca nie pozostawil testamentu lub zawartego w nim powołania spadkobiercy nie dało się z wyżej wskazanych względów utrzymać, wchodziły w grę ogólne przepisy kodeksu cywilnego określające porządek dziedziczenia ustawowego, z tym że w przypadku, gdy w tej samej kolejności powołanych było kilka osób, gospodarstwo dziedziczyła ta z nich, która pracowała wspólnie ze spadkodawcą w spadkowym majątku rodzinnym, a gdy i takich osób było więcej niż jedna, do dziedziczenia dochodziła najstarsza z nich, przy czym mężczyzna wyłączał kobietę ${ }^{12}$.

Warto zwrócić uwagę, że ustawodawca hiszpański czerpie tu ze wzorów germańskiego systemu dziedziczenia gospodarstw rolnych. Nie mówi bowiem o niepodzielnym przyznaniu gospodarstwa w toku działu spadku, jak to miało miejsce w przypadku zwykłych „gospodarstw rodzinnych”, ale określa, kto w konkretnej sytuacji w ogóle dziedziczy majątek rodzinny. Osoba dziedzicząca majątek rodzinny była również chroniona przed nadmiernymi 


\section{Okres surowej reglamentacji - ustawa numer 49/1981 z dnia 24 grudnia 1981 roku o statusie rodzinnego gospodarstwa rolnego oraz młodych rolników}

Przełom lat siedemdziesiątych i osiemdziesiątych w Hiszpanii to okres gorączkowego dostosowywania ustawodawstwa rolnego do aquis communautaire w zakresie Wspólnej Polityki Rolnej, poprzedzający akcesję Hiszpanii do EWG, która nastąpiła w 1981 roku. Podstawowym aktem prawnym ukierunkowanym na harmonizację hiszpańskiego ustawodawstwa rolnego z prawem europejskim była właśnie cytowana ustawa z 1981 roku $^{13}$. Jej autorzy nie kryli zresztą, że jednym z podstawowych źródeł ich inspiracji były znane dyrektywy Rady z roku 1972, przede wszystkim „odstąpieniowa”"14, ale i „,modernizacyjna”"15. Rozwiązania przyjęte w tym akcie normatywnym nie stanowiły jednak bynajmniej zwykłego powtórzenia norm prawa europejskiego. Wręcz przeciwnie, ustawa ta była ,istotnym etapem w rozwoju hiszpańskiej regulacji prawnej dotyczącej gospodarstw rodzinnych", zawierając nadspodziewanie dużo ,oryginalnych koncepcji”"16. Ustawa była zatem aktem prawnym o charakterze niemal rewolucyjnym, zmieniającym całkowicie np. tradycyjne zasady dziedziczenia gospodarstw, które według niej uzyskiwały status ,rodzinnych”. Być może zresztą właśnie ta ,pionierskość” ustawy doprowadziła do tego, że nie przyjęła się jednak dobrze w warunkach hiszpańskich, a co za tym idzie utraciła moc w 1995 roku. Niemniej zastosowane w niej rozwiązania z całą pewnością zasługują na uwagę, również z punktu rozważanej w niniejszym opracowaniu problematyki.

Cytowany akt prawny na plan pierwszy wysuwał pojęcie „rodzinnego gospodarstwa rolnego”, które w sposób bardzo rozbudowany definiował jako „kompleks dóbr i praw, zorganizowanych przez właściciela (titular) w celach prowadzenia produkcji rolnej, przede wszystkim na cele rynkowe, pod warunkiem wszelako, że stanowiło podstawowy środek życia rodziny zapewniający jej utrzymanie na poziomie socjoekonomicznym, analogicznym do innych sektorów gospodarki”.

Dużą uwagę ustawa przywiązywała do odpowiednich kwalifikacji osoby prowadzącej gospodarstwo rodzinne oraz innych osób w nim zamieszkujących. Ten sam przepis art. 2 cytowanej ustawy, który definiował gospodarstwo rodzinne, stawiał przed jego właścicielem wymóg, by prowadzona przezeń działalność rolnicza miała charakter podstawowy w stosunku do jego pozostałej działalności zawodo-

spłatami, które zawsze musiała ponosić na rzecz spadkobierców koniecznych. Spłaty te bowiem, zgodnie z art. 42 dekretu, nie mogły przekraczać jednej trzeciej wartości całego majątku rodzinnego.

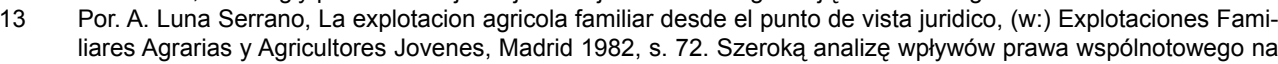
ustawę z 1981 roku przeprowadza również J. Diaz Fraile, El derecho comunitario sobre estructuras agrarias y su desarollo normativo en el derecho espanol, Madrid 1990, s. 185 i n.

16 A. Lichorowicz, Status prawny gospodarstw rodzinnych..., op. cit., s. 124. 
wej, jak również by ponosił on bezpośrednio wszelkie ryzyko związane z prowadzonym przez siebie gospodarstwem. Dodatkowo ustawa stanowiła, że funkcjonowanie gospodarstwa powinno opierać się zasadniczo na osobistej pracy jego właściciela i jego rodziny, przesądzając, że ilość dniówek przepracowanych przez opłacanych pracowników najemnych, nie powinna w skali roku przekroczyć czasu pracy rodziny rolniczej ${ }^{17}$.

Tak definiowane gospodarstwa rodzinne korzystały z szeregu udogodnień, wśród których podstawowe znaczenie miały:

- finansowe wsparcie ze strony państwa inwestycji dokonywanych w gospodarstwach rodzinnych, mających na celu modyfikację struktury produkcyjnej tych gospodarstw, zmierzającą do wzrostu poziomu produkcji, poprawy rezultatów ekonomicznych oraz warunków pracy,

- daleko idące ulgi podatkowe, do których należało całkowite zwolnienie z jakichkolwiek podatków oraz obniżenie o $90 \%$ opłat notarialnych płaconych przy czynnościach prawnych mających na celu nabycie nieruchomości o obszarze wystarczającym do utworzenia rodzinnego gospodarstwa rolnego, jak również zwolnienie od podatku od transmisji majątkowych (Impuesto de Transmisiones Patrimoniales y Actos Juridicos Documentados), wszelkich kredytów udzielanych na podstawie ustawy, jak również poręczeń takich kredytów.

Jednakże, poza wszystkimi wyżej opisanymi przywilejami, właściciel gospodarstwa rodzinnego obarczony był również szeregiem uciążliwych niejednokrotnie obowiązków, dyktowanych przede wszystkim potrzebą ochrony integralności tej kategorii gospodarstw. Do najistotniejszych należał wymóg uzyskania zezwolenia Ministerstwa Rolnictwa na odłączenie jakiegokolwiek elementu wchodzącego w skład gospodarstwa rodzinnego. Żeby z kolei minister rolnictwa mógł wyrazić taką zgodę, musiała zostać spełniona jedna ze wskazanych w ustawie przesłanek, tzn.:

- odłączany element miał utworzyć nowe gospodarstwo rodzinne lub wejść w skład już istniejącego gospodarstwa rodzinnego, albo

- z przyczyn niezależnych od woli właściciela miała nastąpić zmiana rolniczego przeznaczenia odłączanego elementu gospodarstwa, albo

- odłączenie jednego z elementów gospodarstwa uzasadnione było poprawą jego struktury.

17 Na temat związków między definicją właściciela gospodarstwa rodzinnego a pojęciem tzw. „rolnika zajmującego się głównie rolnictwem”, wprowadzonym przepisami wyżej powołanej dyrektywy „modernizacyjnej” z 1972 roku, szeroko pisze A. Carozza, Originalidad y complejidad de la aproximacion espanola a una tematica de fundamental imoprtancia para el Derecho Agrario de los años ochenta, (w:) Explotaciones Familiares Agrarias y Agricultores Jovenes, Madrid 1982, s. 32; por. także A. Luna Serrano, La explotacion agricola familiar..., op. cit., s. 25. 
Niewątpliwie największy ciężar gatunkowy miała pierwsza z wyżej wymienionych podstaw wydania przez ministra zgody na odłączenie (zbycie) składnika lub składników gospodarstwa rodzinnego. Był to równocześnie jeszcze jeden dowód uprzywilejowanego traktowania właścicieli gospodarstw rodzinnych, bowiem jeśli odłączany (zbywany) element miał utworzyć nowe gospodarstwo rodzinne lub wejść w skład już istniejącego gospodarstwa rodzinnego, to osoba nabywcy była ściśle określona. Innymi słowy - nabywcą składnika gospodarstwa rodzinnego mógł być co do zasady wyłącznie właściciel innego gospodarstwa rodzinnego.

Ustawa z 1981 roku nie ograniczała się jednak wyłącznie do surowej, administracyjnej reglamentacji obrotu inter vivos nieruchomościami wchodzącymi w skład gospodarstw rodzinnych, bowiem wprowadzała również szczególne unormowania w zakresie dziedziczenia gospodarstw rodzinnych, odwołujące się tym razem do germańskiego systemu dziedziczenia tych jednostek produkcyjnych, których zasadniczym celem było doprowadzenie do odziedziczenia gospodarstwa rodzinnego w całości przez jedną osobę. Uregulowania te połączone były ze szczególną instytucją o charakterze podmiotowym, tzw. współpracownikiem w rodzinnym gospodarstwie rolnym (colaborador de la Explotación Familiar Agraria), a więc osobą, która zawarła $\mathrm{z}$ właścicielem gospodarstwa tzw. umowę o współpracę ${ }^{18}$.

Umowa o współpracę pomiędzy właścicielem gospodarstwa rodzinnego a współpracownikiem mogła być wzbogacona również o umowę o dziedziczenie (pacto sucesorio), wskazującą tegoż współpracownika jako spadkobiercę gospodarstwa. W doktrynie hiszpańskiej rychło dostrzeżono rewolucyjność tego rozwiązania, przejawiającą się nie tylko w zerwaniu z tradycyjnym, obowiązującym również w Hiszpanii zakazem zawierania umów o dziedziczenie. Na podstawie umowy o dziedziczenie mogli być powołani do dziedziczenia tylko ci spośród spadkobierców ustawowych, którzy spełniali wszystkie przesłanki konieczne dla uzyskania statusu współpracownika lub też zobowiązali się do jego uzyskania ${ }^{19}$. Innymi słowy, sam fakt bycia spadkobiercą ustawowym, bez posiadania statusu współpracownika nie wystarczał do skutecznego odziedziczenia gospodarstwa rolnego na podstawie tego tytułu. $Z$ drugiej strony, osoba spoza najbliższego kręgu rodzinnego właściciela gospodarstwa rodzinnego, w pewnych wypadkach, mogła skutecznie dojść do dziedziczenia tegoż gospodarstwa wyłącznie z tego względu, że dysponowała statusem współpracownika.

J.M. Caballero Gonzales, Los colaboradores en el Proyecto de Ley del Estatuto de la Explotación Familiar Agraria y de los Jóvenes Agricultores, (w:) Explotaciones Familiares Agrarias y Agricultores Jovenes, Madrid 1982, s. 95 in.

Zgodnie z przepisem art. 5 przedmiotowej ustawy, współpracownik, oprócz podpisania z właścicielem gospodarstwa rodzinnego umowy o współpracę, powinien być jego małżonkiem, zstępnym lub innym krewnym oraz posiadać doświadczenie zawodowe minimum dwóch lat pracy w rolnictwie, w którym to okresie praca w gospodarstwie rodzinnym stanowiła jej podstawowe zajęcie. 
Umowa o dziedziczenie, będąca nieobligatoryjnym elementem umowy o współpracę, dawała zatem współpracownikowi pewność nabycia w przyszłości gospodarstwa rolnego, w którym miał pracować w tym charakterze ${ }^{20}$. Umowa o dziedziczenie wyprzedzała również pozostałe dwa tytuły powołania spadkobiercy rodzinnego gospodarstwa rolnego, tj. testament i ustawę, które wchodziły w grę dopiero w jej braku $^{21}$.

Surowość przyjętych w ustawie z 1981 roku regulacji nie spotkała się jednak z przychylnym przyjęciem wśród rolników. Jak się wydaje, podstawowe znaczenie miała w tym względzie obcość hiszpańskiej tradycji obrotu gruntami rolnymi, jak również anachroniczność zastosowanych rozwiązań, prowadząca do zbyt głębokiej ingerencji w kwestie własnościowe i utrudniająca tym samym obrót nieruchomościami rolnymi lub szerzej gospodarstwami rolnymi, a co za tym idzie - nie odpowiadająca potrzebom uczestników tego obrotu.

\section{Okres stopniowej liberalizacji - ustawa numer 19/1995 z dnia 4 lipca 1995 roku o modernizacji gospodarstw rolnych}

Przedmiotowy akt prawny stanowi kolejny punkt zwrotny w historii legislacji prawnorolnej w Hiszpanii. Najważniejszą zmianą jest niewątpliwie rezygnacja z całego rozbudowanego instrumentarium prawnego odnoszącego się do rodzinnych gospodarstw rolnych i ich ochrony ${ }^{22}$. Koncepcja „rodzinnego gospodarstwa rolnego" zastąpiona zostaje pojęciem „gospodarstwa rolnego priorytetowego" (explotacion agraria prioritaria). Gospodarstwo priorytetowe wciąż określane jest w pierwszym rzędzie przez kryteria odnoszące się do osoby, która je prowadzi, elementy przedmiotowe schodzą zaś na drugi plan. U podstawy definicji gospodarstwa priorytetowego leży koncepcja tzw. „rolnika zawodowego” (agricultor profesional), tzn. „osoby fizycznej, która będąc właścicielem gospodarstwa rolnego, przynajmniej $50 \%$ wszystkich swoich dochodów osiąga z działalności rolniczej i innych czynności uzupełniających, pod warunkiem wszelako, że dochód z działalności rolniczej prowadzonej bezpośrednio w jej gospodarstwie nie jest niższy niż $25 \%$ wszystkich jej dochodów i która poświęca na działalność rolniczą i czynności uzupełniające powyżej połowy ogółu swojego czasu pracy”.

Szerzej na ten temat: L. Escandell, La insercion de los jovenes agricultores en la Explotacion Familiar Agraria, (w:) Explotaciones Familiares Agrarias y Agricultores Jovenes, Madrid 1982, s. 73 i n. 21 Por. M. Llombart Bosch, Algunos aspectos de la succesion testament aria y en particular El testamento manAgrarias y Agricultores Jovenes, Madrid 1982, s. 214 i n.; C. Vattier Fuenzalida, La transmission "mortis causa de la Explotacion Familiar Agraria, (w:) Explotaciones Familiares Agrarias y Agricultores Jovenes, Madrid 1982, s. 113 in. 
Wyłącznie rolnik zawodowy może być właścicielem „,indywidualnego gospodarstwa priorytetowego". Ponadto, by prowadzone przez niego gospodarstwo mogło uzyskać status priorytetowego, rolnik taki musi spełniać również dalsze kryteria, a to:

- powinien zorganizować dobra i prawa wchodzące w skład gospodarstwa według kryteriów gospodarki towarowej,

- powinien posiadać odpowiednie kwalifikacje zawodowe ${ }^{23}$,

- powinien podlegać specjalnemu rolniczemu ubezpieczeniu na własny rachunek w związku z prowadzoną działalnością rolniczą,

- powinien zamieszkiwać w gminie (comarca), w której położone jest gospodarstwo lub w gminie sąsiedniej.

Oprócz wyżej opisanych wymogów kierowanych w stosunku do osoby właściciela gospodarstwa rolnego, taka jednostka produkcyjna, by uzyskać status gospodarstwa priorytetowego musi dodatkowo umożliwiać zatrudnienie jednej jednostki pracy rolniczej oraz przynosić dochód w granicach 35-120\% przeciętnego wynagrodzenia uzyskiwanego poza sektorem rolniczym.

Zastępując pojęcie gospodarstwa rodzinnego koncepcją gospodarstwa priorytetowego, ustawa z 1995 roku rezygnuje z ograniczeń obrotu gruntami rolnymi, polegającymi na administracyjnej kontroli tego obrotu. W to miejsce rolnikom spełniającym wyżej wymienione kryteria ustawodawca zapewnia daleko idące preferencje przede wszystkim w zakresie nabywania nieruchomości rolnych mających wejść w skład gospodarstw priorytetowych, między innymi poprzez akcję nadawania tych gruntów przez organy administracji publicznej. W ten sposób zachęca się rolników zawodowych do tworzenia preferowanych przez ustawodawcę jednostek produkcyjnych.

Poza opisanym instrumentem wsparcia bezpośredniego, rolnikom zawodowym ułatwia się również pozyskiwanie gruntów poprzez daleko idące przywileje podatkowe. Takie preferencje o charakterze pośrednim ustawodawca hiszpański przewiduje w następujących wypadkach:

- w przypadku zbycia lub nabycia pod jakimkolwiek tytułem prawnym odpłatnym lub darmym, inter vivos lub mortis causa, prawa własności lub dożywotniego użytkowania gospodarstwa rolnego en bloc, przez rolnika zawodowego - właściciela gospodarstwa priorytetowego, lub też gospodarstwa, które uzyska taki status na skutek powyższego zdarzenia prawnego, obniża się o $90 \%$ podstawę opodatkowania przy wymiarze podatku obciążającego to zdarzenie prawne, pod warunkiem wszelako, że skutkiem tego zdarzenia 
Ewolucja szczególnej regulacji obrotu gruntami rolnymi w ustawodawstwie hiszpańskim

nie będzie utrata przez gospodarstwo nabywcy statusu gospodarstwa priorytetowego,

- w przypadku zbycia lub nabycia pod jakimkolwiek tytułem prawnym odpłatnym lub darmym, inter vivos lub mortis causa, prawa własności lub dożywotniego użytkowania nieruchomości rolnej lub części gospodarstwa rolnego przez rolnika zawodowego - właściciela gospodarstwa priorytetowego, które na skutek powyższego zdarzenia nie traci swojego statusu, obniża się o $75 \%$ podstawę opodatkowania przy wymiarze podatku obciążającego to zdarzenie prawne,

- wszelkie opłaty notarialne oraz koszty wpisów do rejestru własności (ksiąg wieczystych), gruntów wchodzących w skład gospodarstwa priorytetowego, ulegają redukcji o $90 \%$.

Wymienione wyżej instrumenty finansowe nie są jednak jedynymi środkami prawnymi przewidzianymi przez ustawę z 1995 roku, zmierzającymi do utrzymania prawidłowej struktury gospodarstw rolnych. W tym celu hiszpański ustawodawca przewidział bowiem dwie dalsze istotne instytucje, tzn. tzw. ,,minimalną jednostkę upraw" oraz znajdujące stosunkowo szerokie zastosowanie prawa pierwokupu oraz wykupu.

Minimalna jednostka upraw (unidad minima de cultivo) wprowadzona została ustawą z 1995 roku, ale zasadniczo kontynuuje analogiczne rozwiązania przyjęte już w dekrecie numer 118 z 1973 roku. Analizowana ustawa definiuje minimalną jednostkę upraw, w sposób nieco nieprecyzyjny, jako powierzchnię, którą powinna mieć nieruchomość rolna, by uprawy na niej dokonywane, przy zastosowaniu normalnych środków produkcji i technik rolniczych, dostarczały jej właścicielowi zadowalające dochody, przy uwzględnieniu charakterystyki socjoekonomicznej danej jednostki podziału terytorialnego, w której nieruchomość jest położona. Skonkretyzowanie tej definicji powierzone zostało jednakże poszczególnym Regionom, które określają obszar minimalnej jednostki upraw oddzielnie dla każdej z gmin (comarcas) oraz stref (zonas) położonych w ich granicach. Charakterystyczną cechą hiszpańskiej regulacji minimalnej jednostki upraw jest okoliczność, że podział nieruchomości może nastąpić wyłącznie z zachowaniem tej normy obszarowej. Innymi słowy, wszelkie czynności lub zdarzenia prawne, dobrowolne lub nie, prowadzące do podziału danej nieruchomości, w wyniku którego powstałyby nowe nieruchomości o powierzchni mniejszej niż przedmiotowa norma obszarowa, są nieważne i nie wywołują skutków prawnych między stronami tych czynności ani też wobec osób trzecich, co expressis verbis przewiduje przepis art. 24 cyt. ustawy ${ }^{24}$. 
Ten sam akt prawny przewiduje jednak również wyjątki od surowej sankcji bezwzględnej nieważności czynności prawnych nierespektujących minimalnej jednostki upraw. Dopuszczalny jest bowiem podział nieruchomości nieuwzględniający tej normy obszarowej, gdy:

- zbycie nieruchomości powstałej w wyniku podziału następuje na rzecz właściciela nieruchomości sąsiedniej, pod warunkiem wszelako, że ani nieruchomość ulegająca podziałowi, ani nieruchomość sąsiednia, na skutek tego podziału nie osiągnie obszaru powierzchni mniejszej niż minimalna jednostka upraw,

- nieruchomość powstała na skutek podziału zostanie przeznaczona, w ciągu roku następującego po podziale, na cele przemysłowe lub inne o charakterze nierolniczym, pod warunkiem wcześniejszego uzyskania stosownego pozwolenia na budowę,

- podział nieruchomości jest następstwem nabycia jej własności na podstawie przepisów o dzierżawie rolniczej,

- podział następuje na skutek wywłaszczenia ${ }^{25}$.

Do dalszych instrumentów ingerujących w swobodny obrót gruntami rolnymi, przewidzianych ustawą z 1995 roku należy sąsiedzkie prawo wykupu przysługujące również rolnikom zawodowym-właścicielom gospodarstw priorytetowych. Instytucja ta powiązana jest ściśle $\mathrm{z}$ reżimem minimalnej jednostki upraw i polega na tym, że w przypadku sprzedaży nieruchomości rolnej o powierzchni mniejszej niż dwukrotność minimalnej jednostki upraw (unidad minima de cultivo), prawo wykupu tej nieruchomości przysługuje właścicielom nieruchomości sąsiedniej, pod warunkiem wszelako, że są rolnikami zawodowymi - właścicielami gospodarstw priorytetowych.

W interesujący sposób ustawodawca hiszpański uregulował również sytuację zbiegu sąsiedzkich praw wykupu. W takim wypadku, tj. gdy w konkretnej sytuacji prawo to przysługuje kilku rolnikom zawodowym, może z niego skorzystać ten z nich, który jest właścicielem nieruchomości, która na skutek skorzystania $\mathrm{z}$ tego prawa osiągnie lub przekroczy obszar odpowiadający minimalnej jednostce upraw. W sytuacji zaś, gdy i ten wymóg spełnia kilku z rolników zawodowych, prawo wykupu przysługiwać będzie temu, który jest właścicielem nieruchomości o najmniejszej powierzchni. W konkretnym wypadku może jednak zdarzyć się i tak, że żadna z sąsiadujących nieruchomości na skutek skorzystania przez jej właściciela z prawa wykupu nie osiągnie rozmiarów odpowiadających minimalnej jednostce upraw. Wtedy, zgodnie

O minimalnej jednostce upraw i jej praktycznym zastosowaniu w ustawodawstwie hiszpańskim, poprzedzającym ustawę z 1995 roku pisze między innymi również A. Lichorowicz, Zagadnienie dopuszczalności podziału gospodarstwa rolnego (ze szczególnym uwzględnieniem roli notariusza), (w:) Księga pamiątkowa I Kongresu Notariuszy RP, Kluczbork 1994. 
z zasadą ochrony najbardziej wydajnych struktur rolniczych, preferowany będzie właściciel nieruchomości o największej powierzchni.

Ustawodawca daje rolnikom zawodowym - właścicielom nieruchomości wchodzących w skład gospodarstw priorytetowych jeden rok na skorzystanie z przysługującego im sąsiedzkiego prawa wykupu, przy czym termin ten biegnie od dnia wpisu nowego właściciela do rejestru własności.

Rolnik zawodowy, korzystający z prawa wykupu sprzedawanej nieruchomości, podlega jednak daleko idącym ograniczeniom w stosunku do nabytego w ten sposób gruntu. Otóż, w ciągu sześciu lat od dnia skorzystania z prawa wykupu nie może dokonać dalszego zbycia przedmiotowego gruntu. Czynność taka, jako sprzeczna $\mathrm{z}$ ustawą, jest bezwzględnie nieważna ${ }^{26}$.

Oprócz tzw. wykupu sąsiedzkiego regulowanego ustawą z 1995 roku, ustawodawca hiszpański przewiduje również szczególne formy pierwokupu i wykupu przysługujących dzierżawcy nieruchomości rolnej, uregulowane w ustawie numer 49 z 26 listopada 2003 roku o dzierżawie rolniczej (ley de arrendamientos rusticos) ${ }^{27}$. Zgodnie z art. 22 cytowanej ustawy, w każdym przypadku przeniesienia własności dzierżawionej nieruchomości, w tym udziału we współwłasności takiej nieruchomości, w drodze czynności prawnej inter vivos, włączając w to umowę darowizny, zamiany oraz wniesienie aportu do spółki, dzierżawcy, dysponującemu statusem rolnika zawodowego, przysługują prawa pierwokupu i wykupu tej nieruchomości.

Zakres przedmiotowy powołanych uprawnień rolnika zawodowego-dzierżawcy nieruchomości rolnej został zatem ukształtowany bardzo szeroko; rozciąga się on nie tylko tradycyjnie na umowę sprzedaży, ale i na inne czynności prawne pociągające za sobą identyczny skutek gospodarczy, jak sprzedaż, a nawet na czynności prowadzące do przeniesienia własności dzierżawionej nieruchomości rolnej pod tytułem darmym. Przypadki zbycia dzierżawionej nieruchomości rolnej, które nie będą generowały po stronie jej dzierżawcy prawa pierwokupu lub wykupu, będąnależały do rzadkości, choć i takie sytuacje zostały przewidziane przez ustawodawcę. Nie podlegają pierwokupowi ani wykupowi dzierżawcy:

- przeniesienie własności nieruchomości rolnej pod tytułem darmym, o ile nabywcą jest zstępny lub wstępny zbywcy, jego krewny lub powinowaty, aż do drugiego stopnia lub małżonek,

- umowa zamiany nieruchomości rolnych, gdy ma na celu poprawienie rozłogów jednej z zamienianych nieruchomości, pod warunkiem, że łączna powierzchnia obu tych nieruchomości nie przekracza dziesięciu hektarów. 
Powołane sytuacje, w których nie aktualizuje się pierwokup ani wykup dzierżawcy zdają się zasługiwać na uznanie, chroniąc w pierwszym przypadku interesy członków rodziny właściciela zbywanej nieruchomości rolnej, w drugim zaś uwzględniając potrzebę prawidłowego ukształtowania rolniczych struktur produkcyjnych.

Ustawodawca hiszpański stosunkowo drobiazgowo uregulował również procedurę korzystania przez dzierżawcę-rolnika zawodowego, z przysługujących mu praw pierwokupu i wykupu. Obu wymienionym uprawnieniom odpowiada bowiem obowiązek po stronie zbywcy nieruchomości rolnej zawiadomienia dzierżawcy w sposób wyraźny o zamiarze zbycia tej nieruchomości, z podaniem istotnych elementów przyszłej umowy, przede wszystkim uzgodnionej przez strony ceny, a w jej braku, wartości zbywanej nieruchomości. Od chwili powyższego zawiadomienia, rozpoczyna się dla dzierżawcy bieg sześćdziesięciodniowego terminu do skorzystania z prawa pierwokupu zbywanej nieruchomości po cenie i na warunkach, wskazanych w zawiadomieniu. W przypadku zaś braku tego zawiadomienia ze strony wydzierżawiającego, dzierżawca może wykonać prawo wykupu zbytej już nieruchomości w ciągu sześćdziesięciu dni roboczych od chwili, w której powziął wiadomość o dokonanym zbyciu. Dodatkowo, nawet gdyby dzierżawca, mimo uprzedniego zawiadomienia ze strony wydzierżawiającego, nie skorzystał z przysługującego mu prawa pierwokupu, strony umowy przeniesienia własności dzierżawionej przez niego nieruchomości mają obowiązek przedłożyć mu akt notarialny obejmujący tę czynność prawną. Jeśli zaś warunki tej umowy, cena lub osoba nabywcy nie odpowiadają temu, o czym został poprzednio zawiadomiony, dzierżawca-rolnik zawodowy może w ciągu sześćdziesięciu dni roboczych od przedłożenia mu tego aktu notarialnego wykonać przysługujące mu prawo wykupu.

Dzierżawcy przysługują wreszcie szczególne uprawnienia na wypadek gdyby kwestionował on warunki przyjęte przez strony umowy przeniesienia własności dzierżawionej nieruchomości, niezależnie czy doszła już ona do skutku (i korzysta on z prawa wykupu), czy jeszcze nie (i w grę wchodzi pierwokup). Może on bowiem zażądać, by cena (wartość) zbywanej nieruchomości ustalona została przez biegłego, ustanawianego w pierwszej kolejności na podstawie porozumienia samych zainteresowanych, a w jego braku na podstawie stosownego orzeczenia sądu cywilnego.

Ustawa z 2003 roku zawiera również kilka interesujących regulacji dotyczących sytuacji zbiegu praw pierwokupu i wykupu, przysługujących kilku dzierżawcom-rolnikom zawodowym. Zasługują one na przytoczenie in extenso:

- w sytuacji, gdy zbywana jest nieruchomość rolna oddana w całości w dzierżawę kilku rolnikom zawodowym, z których każdy korzysta z niej w odmienny sposób, prawo pierwokupu i wykupu przysługuje wyłącznie temu 
z nich, którego sposób korzystania ma charakter zasadniczy (principal); gdyby zaś nie dało się tego określić, powyższe uprawnienia przysługują rolnikowi zawodowemu, który jednocześnie spełnia kryteria niezbędne do uzyskania statusu młodego rolnika w rozumieniu ustawy z 1995 roku o modernizacji gospodarstw rolnych. Gdyby w konkretnej sytuacji przesłankę tę spełniała więcej niż jedna osoba, z prawa wykupu bądź pierwokupu będzie mogła skorzystać ta z nich, która najdłużej była dzierżawcą zbywanej nieruchomości;

- w przypadku, gdyby fizycznie wydzielone części zbywanej nieruchomości były oddane w dzierżawę kilku rolnikom zawodowym do wyłącznego korzystania, o zamierzonym zbyciu należy powiadomić każdego z nich, zaś prawo pierwokupu lub wykupu będzie mógł wykonać każdy z nich w stosunku do dzierżawionej przez siebie części. Jeśli któryś z nich nie będzie chciał skorzystać z przysługujących mu uprawnień, prawo wykupu lub pierwokupu dzierżawionej przez niego części nieruchomości będzie mógł wykonać którykolwiek z pozostałych dzierżawców, z tym że pierwszeństwo przysługuje młodemu rolnikowi w rozumieniu ustawy z 1995 roku o modernizacji gospodarstw rolnych, a w jego braku osobie, która najwcześniej zawarła umowę dzierżawy.

- w sytuacji, gdy tylko część zbywanej nieruchomości została oddana w dzierżawę, prawa pierwokupu lub wykupu przysługujące dzierżawcy ograniczają się tylko do tej dotychczas dzierżawionej przez niego części ${ }^{28}$.

W ustawie z 1995 roku o modernizacji gospodarstw rolnych ustawodawca hiszpański w istotny osób odszedł od surowej ingerencji w zakresie dziedziczenia tych jednostek produkcyjnych, przyjętej w dekrecie z 1973 roku w odniesieniu do majątków rodzinnych, zaś w ustawie z 1981 roku w stosunku do gospodarstw rodzinnych. Aktualnie niewielka ingerencja w ustalony ogólnymi przepisami prawa spadkowego porządek dziedziczenia związana jest z pojęciem młodego rolnika (agricultor jóven), tzn. osoby, która, zgodnie z art. 2 ust. 7 ustawy, ukończyła osiemnaście lat, a nie przekroczyła czterdziestego roku życia i która prowadzi lub zamierza prowadzić działalność rolniczą.

Młody rolnik - w świetle rozwiązań hiszpańskich - może zasadniczo liczyć na wsparcie ze strony państwa o charakterze fiskalnym. Najważniejsze znaczenie w tym zakresie ma bez wątpienia całkowite zwolnienie od jakichkolwiek podatków zdarzeń prawnych prowadzących do zbycia lub nabycia pod jakimkolwiek tytułem prawnym odpłatnym lub darmym, inter vivos lub mortis causa, prawa własności lub dożywotniego użytkowania gospodarstwa rolnego en bloc, jego części lub pojedyn- 
czych nieruchomości rolnych przez młodego rolnika, rozpoczynającego działalność w gospodarstwie priorytetowym.

Ponadto aktualnie obowiązujące regulacje dają młodemu rolnikowi szansę stania się współprowadzącym gospodarstwo priorytetowe (cotitular), co ma miejsce między innymi wtedy, gdy rolnik zawodowy-właściciel gospodarstwa priorytetowego przeniesie na młodego rolnika udział wynoszący przynajmniej jedną trzecią część we współwłasności elementów wchodzących w skład gospodarstwa priorytetowego i które to elementy utrzymają status składników tego gospodarstwa również po przedmiotowej transakcji ${ }^{29}$.

$\mathrm{Z}$ analizy przedmiotowych regulacji wynika, że młody rolnik-współprowadzący gospodarstwo priorytetowe posiada obecnie zdecydowanie mocniejszą pozycję od współpracownika w gospodarstwie rodzinnym na gruncie ustawy z 1981 roku, w szczególności, jeśli na podstawie stosownej umowy z właścicielem gospodarstwa staje się współwłaścicielem tej jednostki produkcyjnej. Dawna umowa o współpracę, jeżeli dodatkowo zawierała umowę o dziedziczenie, dawała współpracownikowi wyłącznie perspektywę odziedziczenia gospodarstwa rodzinnego, w którym zobowiązywał się pracować. W świetle obowiązujących przepisów młody rolnik-współprowadzący gospodarstwo priorytetowe uzyskuje natomiast bezpośredni wpływ na decyzje gospodarcze podejmowane w gospodarstwie, partycypuje w jego dochodach, jak i stratach w zakresie określonym w umowie, ponosi ryzyko prowadzonej działalności, a nawet ma szansę nabycia współwłasności tej jednostki produkcyjnej już za życia jej właściciela, co może mieć następnie istotne znaczenie przy dokonywaniu działu spadku lub zniesienia współwłasności.

Nowe typy „umowy o współprowadzenie" nie dają natomiast młodemu rolnikowi żadnych bezpośrednich praw do dziedziczenia tej jednostki produkcyjnej, jak to miało miejsce w umowie o współpracę regulowanej przepisami ustawy z 1981 roku. W 1995 roku ustawodawca hiszpański zerwał bowiem całkowicie z dawnym, i jak się okazało w praktyce nieefektywnym, systemem dziedziczenia gospodarstwa rodzinnego przez współpracownika na podstawie zawartej z jego właścicielem umowy o dziedziczenie, znacznie liberalizując w tym zakresie stosowne przepisy. Odtąd kontrola struktur rolniczych w toku spadkobrania przesunięta została zgodnie z romańską tradycją na moment działu spadku, a jedynym jej instrumentem stała się wspominana już instytucja minimalnej jednostki upraw, która nie dopuszcza, by również na podstawie działu spadku lub zniesienia współwłasności powstały gospodarstwa mniejsze od tej jednostki referencyjnej. Dla młodego rolnika-współprowadzącego gospodarstwo priorytetowe, o ile stał się on współwłaścicielem tej jednostki produkcyjnej na podstawie umowy o współprowadzenie, nowy system dziedziczespodarstwa priorytetowego dla swej ważności powinno zostać dodatkowo wpisane do rejestru własności. 
nia odgrywa jednak pewną rolę, choć jest to już zasadniczo oddziaływanie pośrednie. Jego analiza wymaga rozważenia dwóch odmiennych sytuacji:

- współprowadzący gospodarstwo priorytetowe może być w konkretnym przypadku jednym ze spadkobierców np. ustawowych właściciela tej jednostki produkcyjnej. W takiej sytuacji, ze względu na wymóg zachowania minimalnej jednostki upraw, preferowanym sposobem działu spadku będzie zasadniczo przyznanie spadkowego gospodarstwa na wyłączną własność jednemu ze spadkobierców, którym, jak wskazuje praktyka, najczęściej jest właśnie osoba, która posiadała status współprowadzącego,

- współprowadzący może być również osobą obcą w stosunku do właściciela gospodarstwa priorytetowego w rozumieniu przepisów prawa spadkowego. Nie będzie on brał zatem udziału w dziale spadku po nim, jednakże może w następnej kolejności wystąpić z żądaniem zniesienia współwłasności wobec spadkobierców dziedziczących gospodarstwo. W takim przypadku znów zadziała zasada minimalnej jednostki upraw, a co za tym idzie, gospodarstwo przyznane zostanie w całości osobie, która przed otwarciem spadku posiadała status współprowadzącego ${ }^{30}$.

\section{Podsumowanie}

Ustawodawstwo hiszpańskie w zakresie będącej przedmiotem niniejszej pracy problematyki obrotu gruntami rolnymi zaskakuje wręcz swoją różnorodnością. Poczyniona powyżej analiza najważniejszych aktów prawnych odnoszących się do tego zagadnienia pozwala jednak na wyciągnięcie kilku subiektywnych wniosków o charakterze nieco ogólniejszym, jak również wskazanie tych rozwiązań, które jak się wydaje, szczególnie zasługują na uwagę.

Niewątpliwie przyczyna owej zmienności ustawodawstwa hiszpańskiego, rewolucyjnych zmian przynoszonych przez każdy nowy akt prawny, leży w daleko posuniętym braku oryginalności tego porządku prawnego. Powyżej analizowane unormowania z reguły inspirowane były rozwiązaniami o obcej proweniencji. Tak było w przypadku regulacji dotyczących reformy rolnej, przy których tworzeniu czerpano przede wszystkim z włoskich doświadczeń. Stosunkowo najbardziej oryginalne rozwiązania, zastosowane w ustawie z 1981 roku, nie przyjęły się jednak w praktyce i z tego też powodu zostały uchylone. Niemniej nie należy zapominać, że również tamta ustawa w dużym stopniu powielała obce wzorce, czego najlepszym dowodem jest chociażby wprowadzenie do hiszpańskiego porządku prawnego elementów germańskiego systemu dziedziczenia rodzinnych gospodarstw rolnych. Obowiązująca zaś aktualnie ustawa z 1995 roku również wykorzystuje, a niekiedy twórczo prze- 
kształca niektóre instytucje wspólnotowego prawa rolnego, takie jak np. dwa pojęcia o charakterze podmiotowym, tzn. młodzi rolnicy oraz rolnicy zawodowi.

Jeśli zaś chodzi o przyjęte metody oddziaływania na obrót nieruchomościami rolnymi, prawnej ingerencji w swobodę uczestników tego obrotu, to zwraca uwagę tendencja zmierzająca do stopniowej liberalizacji regulacji prawnych. Tendencja ta wyraża się w zastępowaniu różnorodnych metod o charakterze administracyjnoprawnym, takich jak np. system zezwoleń na podział gospodarstw rodzinnych, funkcjonujący na gruncie ustawy z 1981 roku, środkami o charakterze finansowym i fiskalnym. W aktualnie obowiązującej ustawie z 1995 roku, to właśnie te ostatnie odgrywają najważniejszą rolę, zapewniając rolnikom zawodowym nabywającym grunty rolne, mające wejść w skład istniejących lub utworzyć nowe gospodarstwa priorytetowe, daleko posunięte preferencje podatkowe oraz zwolnienia i ulgi z innych opłat (np. notarialnych). W ten pośredni sposób zachęca się zatem odpowiednio wykwalifikowanych rolników do nabywania nieruchomości rolnych i tworzenia tą drogą efektywnych i wydajnych gospodarstw, o obszarze optymalnym z punktu widzenia zasad prawidłowej gospodarki rolnej. Jednocześnie przyjęty system nie wyklucza a priori możliwości nabywania własności rolniczej przez osoby nieposiadające statusu rolnika zawodowego, które jednak nie mogą skorzystać z powołanego systemu ulg i preferencji.

Ustawodawca hiszpański nie rezygnuje jednak również całkowicie z instrumentów o charakterze cywilnoprawnym, wśród których podstawowe znaczenie utrzymały przysługujące rolnikom zawodowym: sąsiedzkie prawo wykupu oraz prawo pierwokupu i wykupu dzierżawcy. Prawna regulacja tych instytucji zasługuje, jak się zdaje, na szczególną uwagę, ze względu na wciąż niewystarczające wykorzystanie pierwokupu dla prawidłowego kształtowania struktur rolnych w ustawodawstwie polskim, mimo wielokrotnie podnoszących się w polskiej literaturze głosów, domagających się szerszego uwzględnienia tej instytucji w ramach polskich regulacji prawnorolnych ${ }^{31}$.

Jak zatem wynika z wyżej poczynionych analiz, ewidentna tendencja zmierzająca do uwolnienia obrotu gruntami rolnymi w Hiszpanii od gorsetu administracyjnych zakazów i nakazów, zbliża ten system prawny do koncepcji obowiązujących po 1990 roku w ustawodawstwie polskim, których zasadniczo nie zmieniło wejście w życie wielce niedoskonałej ustawy z dnia 11 kwietnia 2003 roku o kształtowaniu ustroju rolnego ${ }^{32}$. Nie można jednak zapominać, że ustawodawca hiszpański nie zrezygnował całkowicie z jakichkolwiek norm obszarowych, utrzymując instytucję minimalnej jednostki upraw jako narzędzie zapobiegania nieracjonalnym podzia- 
łom nieruchomości rolnych. Co więcej, w ustawodawstwie hiszpańskim, począwszy od dekretu o reformie i rozwoju rolnictwa z 1973 roku, doskonale widoczna jest troska o utrzymanie istniejących i utworzenie nowych gospodarstw rolnych, które ze względu na przyjęte kryteria, w sposób optymalny realizują przyjęte przez państwo założenia prawidłowej gospodarki rolnej. Tym tłumaczyć należy mnogość różnorodnych definicji, poczynając od majątków rodzinnych w dekrecie z 1973 roku, poprzez gospodarstwa rodzinne w ustawie z 1981 roku, aż po gospodarstwa priorytetowe z 1995 roku. Można zatem powiedzieć, że przedmiotem ochrony ze strony regulacji ingerujących w obrót nieruchomościami rolnymi zarówno inter vivos, jak i mortis causa, jest w Hiszpanii nie tyle sama nieruchomość rolna, jej obszar oraz inne parametry, ale przede wszystkim gospodarstwo rolne, czyli jednostka produkcyjna jako taka. Ta cecha rozwiązań hiszpańskich zdaje się w największym stopniu odbiegać od ich odpowiedników obowiązujących w polskim systemie prawa rolnego, gdzie ustawodawca ingerował i nadal ingeruje w obrót gruntami rolnymi, otaczając szczególną troską same nieruchomości rolne (najczęściej ich obszar), niezależnie od faktu czy wchodzą one w skład konkretnego gospodarstwa rolnego. Tymczasem, jak się wydaje, to nie same nieruchomości rolne w rozumieniu art. $46^{1}$ kodeksu cywilnego zasługują na szczególną ochronę w ramach prawnej regulacji obrotu takimi gruntami, a raczej dopiero gospodarstwa rolne zorganizowane na takich nieruchomościach rolnych. Być może dostrzeżenie tego problemu przez ustawodawcę hiszpańskiego powinno stanowić główne źródło inspiracji w zakresie ewentualnych zmian polskich regulacji reglamentujących obrót nieruchomościami rolnymi.

Poza wyżej omówionymi postulatami, dotyczącymi szerszego uwzględnienia prawa pierwokupu lub wykupu w regulacji obrotu nieruchomościami rolnymi oraz nowego spojrzenia na przedmiot ochrony tej regulacji, poprzez odwołanie się do pojęcia gospodarstwa rolnego, a nie samej tylko nieruchomości rolnej, hiszpańskie rozwiązania prawno rolne mogłyby stanowić źródło inspiracji dla polskiego legislatora w jeszcze jednej istotnej kwestii. Chodzi mianowicie o określenie pozycji osób współdziałających z kierownikiem gospodarstwa w jego prowadzeniu, jak również o zapewnienie ciągłości funkcjonowania gospodarstwa rolnego w sytuacji nieuniknionych zmian generacyjnych w rolnictwie, w szczególności w ramach dziedziczenia gospodarstw rolnych. $\mathrm{Z}$ tym istotnym i trudnym problemem ustawodawca hiszpański starał się uporać już w ustawie z 1981 roku, powołując do życia instytucję współpracownika w rodzinnym gospodarstwie rolnym, obecnie zaś interesującą próbą jego rozwiązania jest pojęcie młodego rolnika-współprowadzącego gospodarstwo priorytetowe w ustawie z 1995 roku. Fakt obowiązywania tego podmiotowego pojęcia, wyodrębnianego za pomocą ściśle określonych kryteriów, pozwala przyjąć, że ustawodawca hiszpański dostrzega istotę ,prowadzenia” indywidualnego gospodarstwa rolnego, które tylko wyjątkowo polega na sprawowaniu wszystkich funkcji kierowniczych wyłącznie przez jedną osobę. Znacznie częściej prowadzenie gospo- 
darstwa zakłada w rzeczywistości współdziałanie kilku osób, najczęściej zresztą ze sobą spokrewnionych. Poza określeniem pozycji „,współprowadzącego” w ramach istniejącego gospodarstwa rolnego, ustawodawca hiszpański nadaje takiej osobie również określone preferencje w zakresie dojścia do tej jednostki produkcyjnej na płaszczyźnie obrotu mortis causa, dążąc do zapewnienia ciągłości funkcjonowania spadkowej jednostki produkcyjnej. Obie powyższe kwestie pozostają zaś na dzień dzisiejszy poza polem zainteresowania polskiego legislatora, mimo że bez wątpienia odgrywają istotną rolę jako narzędzie kształtowania prawidłowych struktur rolnych. Zatem również i w tym zakresie unormowania hiszpańskie mogłyby znaleźć odpowiednie zastosowanie w polskiej regulacji obrotu nieruchomościami rolnymi.

Podsumowując powyższe rozważania, podkreślić należy, że hiszpańskie ustawodawstwo rolne, mimo braku oryginalności stosowanych rozwiązań, stanowi jednak dobry wzór twórczego adaptowania obcych regulacji do miejscowych warunków i w tym zakresie niewątpliwie stanowić może punkt odniesienia dla dalszych poszukiwań legislacyjnych także polskiego ustawodawcy. 


\section{An evolution of the particular regulation of agricultural real estates circulation in the Spanish legislation}

\section{Summary}

Spanish agricultural legislation in the field of agricultural real estates circulation with passage of time has undergone great changes and modifications. The characteristic feature of the Spanish legal order are frequent and frenetic quests after an optimum agricultural real estates circulation model, which would perfectly correspond with Spanish social - economic conditions. All the most important changes in the hitherto existing conceptions are signed by the dates of coming into force of three legal acts of the principal importance, i.e. decree number 118/1973 of 12th of January 1973 on the agricultural reform and development, law number 49/1981 of 24th of December 1981 on the statute of family agricultural farm and the statute of young farmers and finally law number 19/1995 of 4th of July 1995 on modernization of agricultural farms. Each of the above-mentioned legal acts not only abandoned in the radical way the hitherto existing regulations but also referred to the contemporary tendencies in the field of agricultural real estates circulations, which dominated in the legislation of the other European countries and European Communities. The lack of originality and the broad use of adopted ideas are other typical features of the Spanish regulations.

The aim of this article is to undertake an attempt to characterize the basic tendencies in the development of Spanish legislation in the field of agricultural real estates circulation in their historical aspect, as well as to show the principal influences that Spanish regulations underwent with passage of time. Executed studies allow further to formulate several conclusions on the interesting similarity of basic principles of Spanish and Polish regulations in the field of agricultural real estates circulation, as well as they permit to place some proposals on the possibility of utilization of concrete Spanish regulations in the Polish legal order. One should consider on the one hand the broader use of the institution of the right of preemption in the Polish agricultural legislation. On the other hand, it would be highly beneficial to interfere in the agricultural real estates circulation from the point of view of the protection of agricultural farms as well as to regulate the legal status of the coworkers in the conduct of agricultural farms especially by granting them certain privileges in the field of farm succession. 